\title{
Determinants of Investment Decisions among Agribusiness Investors in South-East, Nigeria
}

\author{
Nwibo, S. U. and Alimba, J. O. \\ Department of Agricultural Economics, Management and Extension Ebonyi State University, Abakaliki, Nigeria
}

\begin{abstract}
The determinants of investment decisions among agribusiness investors in Southeast, Nigeria were studied. The study employed a combination of multistage and purposive sampling techniques in the collection of data from three hundred and sixty (360) agribusiness investors using structured questionnaires. Both descriptive and inferential statistics were employed to realise the objectives of the study. The results of the analysis show that the investors are within their active age (40 -59 years) and are actively involved in farm input supply (60\%), farm processing (55\%), and marketing/distribution (54\%). It was equally observed that investors whose annual income ranges between $\$ 501,000.00$ - $\$ 1,000,000.00$ invested more in farm input supply while investors with annual income of between $\$ 101,000$ - \$500,000 invested more in farm production, processing and distribution of agricultural products. With the Chi-square ( $\left.\chi^{2}\right)$ value of 9368.836 and the Pseudo $R^{2}$ of 0.465 which was grater than the probability level $5 \%(P>0.05)$, the study revealed that the socioeconomics characteristics of agribusiness investors in South East Nigeria have significant effect on determinants of investment decision. Meanwhile, study showed that apart from the socioeconomic characteristics of the investors; experience, source of investment capital, annual income, and household entrepreneurial history, inadequate start-up capital, business location, favourable government policy on entrepreneurship, experience in self employment, high rate of inflation, market size were at $5 \%(P>0.05)$ identified be the determinants of investment decision among agribusiness investors in Southeast Nigeria. The study further revealed that the interrelationship between the entrepreneur's marital status and gender $\left(0.688^{*}\right)$, annual income and level of education $(0.622 *)$, experience and level of education $(0.739 * *)$, and household entrepreneurial history and individual experience $(0.515 *)$ have strong effect on the agribusiness investment decision. Based on the findings, the study recommended the provision of conducive investment climate for agribusiness investors. This entails the provision of those things that will attract both local and foreign direct investments into agribusiness sector. These include tax holidays, investment infrastructures, reduction in social vices such as kidnapping and activities of religious sect - boko haram.
\end{abstract}

Key words: Determinants, investment, decision, agribusiness, investors.

\section{Introduction}

Investment is the present sacrifice for future benefit. Individuals, firms, and governments are all regularly in position to decide whether or not to invest, and how to diverse among the options available. An individual might have to decide whether to buy a stock, plant seeds, undertake a course of training; a firm may decide to purchase machinery or construct building; and government may decide whether or not to build market. Under the heading of investment decision, economists have addressed the problem of how to rationally choose in such situations involving a trade-off between present and future. In view of this, Hirshleifer (1995) identified three elements that are needed to determine individual's investment decision. These include; his endowment in the form of existing stream of income over time, his preference function which orders in desirability all possible time combinations of consumption, and opportunity set which specifies the possibilities for transferring the original endowment into time combination of consumption. Macro and Paolo (2010) inferred that the approach followed by investors in allocating their money accordingly depend on their ability to remember and learn from past experiences. Before choosing how to allocate resources, investors consider many financial data, trying to transform them into useful information. An intriguing approach to describe and, possibly, explain investment decisions may be the explicit consideration of psychological factors (Hawkins and Hastie, 1990).

Investment into agribusiness is widely propagated particularly, by the managers of SMEs projects, and is sometimes believed that because agribusiness returns have a low correlation to other investments, they have the potential to improve returns and reduce risk in a diversified portfolio (Hawkins and Hastie, 1990). A developing country like Nigeria with its high population and market size is a fertile ground for entrepreneurs to invest. Similarly, the abundance of natural agricultural resources is a major pull factor for investment in the agribusiness sector in Nigeria. The economic literature on private capital formation in developing countries has also emphasized issues of uncertainty and risk as disincentives to investment (Jenkins and Thomas, 2002). According to FAO estimate as reported by 3ADI (2010), cumulative global investments required until 2050 in agriculture and downstream support services will reach US\$940 billion in Sub-Saharan Africa alone. Of this 
amount, about 66 percent will be required for agribusiness and agro-industries capital outlays, covering items such as cold and dry storage (US\$ 78 billion), rural and wholesale market facilities (US\$159 billion), first stage processing (US\$207 billion), mechanization (US\$59 billion) and other power sources and equipment (US\$115 billion). These investments will have to be made primarily by the private sector.

Agribusiness is basically agricultural related business which accounts for $12.1 \%$ of Nigeria's Gross Domestic Product (GDP) 2003-2004, and accounts for almost 25\% of national merchandise exports $(\$ 26.1$ billion in 2003-2004), and it is the biggest manufacturing sector and accounts for $46 \%$ of total retail spending (Anon, 2010). However, despite the holistic benefits of agribusiness to our nation - Nigeria, there seems to be dearth of knowledge on what drives the agribusiness investors on their investment decisions in South-east, Nigeria. Based on this, the study described the socio-economic characteristics of the agribusiness investors in relation to agribusiness investments in South-East, Nigeria; identified and analysed the determinants of investment decisions among agribusiness investors in the area; and determined the effect of socio-economic characteristics of the agribusiness investors on their investment decisions.

\section{Study Area}

\section{Materials And Methods}

The study area is South-east of Nigeria. The area comprised of six states, namely; Anambra, Imo, Abia, Enugu, and Ebonyi. The area has a total population of 16.4 million people who are mainly of Igbo extraction (NPC, 2006). With an approximated land mass of 58,214.7 square kilometres, the area lies between longitude $6^{0} 50^{I}$ and $8^{0} 30^{I} \mathrm{E}$ latitude $4^{0} 30^{I}$ and $7^{0} 5^{I} \mathrm{~N}$. Atmospheric temperature of the area varies from $18^{0} \mathrm{C}$ to $34^{\circ} \mathrm{C}$ within the year. The area is endowed with abundant natural resources and lots of agricultural activities. The agricultural activities conform to the tri-aggregates of agribusiness which include; farm supply, farm processing and distribution/marketing of processed products.

\section{Sampling Technique}

Both purposive and multistage sampling techniques were employed in the selection of 360 agribusiness investors in the study area.

\section{Data Collection}

Data were collected primarily using structured questionnaire and interview schedule. The construction of the research instrument was based on the study objectives.

\section{Data Analysis}

Both descriptive and inferential statistics were employed in the analysis of the data collected. Descriptive statistics, such as tables, percentages, means, etc was employed to analyse objective (i). Probit regression analysis was employed to realise objective (iii), while objectives (ii), was achieved using factor analysis.

\section{Probit Regression Model}

decision

The socioeconomic characteristics of the agribusiness investors were regressed against investment

The probit model was expressed implicitly as:

$$
I D=\beta_{o}+\beta_{i} X_{i}+e t, \text { and } I D=\beta_{o}+\beta_{i} X_{i}+e_{t} ; \text { and }
$$

Explicitly expressed as:

Where,

$$
I D=\beta_{0}+\beta_{1} A G+\beta_{2} G E N+\beta_{3} L E D+\beta_{4} E X P+\beta_{5} A I+\beta_{6} H H S+\beta_{7} H E H+\beta_{8} S I C+\beta_{9} N E O+\beta_{10} M S+e t
$$

$I D$ is dichotomous dependent variables, which can be explained as: $I D=1$, effect on decision to invest, $I D=0$, no effect on decision to invest, $\beta_{\mathrm{o}}=$ is the intercept, $\beta_{\mathrm{i}}$ are regression coefficients that explain the investment decisions of the agro-entrepreneurs, $X_{i}=$ independent variables, and $e_{t}$ is the error term.

The explanatory variables represented by $\mathrm{X}_{\mathrm{i}}$ are:

$\mathrm{AG}=$ Age of investor (in years)

GEN $\quad=\quad$ Gender of investor $($ male $=0$, female $=1)$

LED $=$ Level of education (highest level of education attained: $F S L C=1$,

$\mathrm{SSCE}=2, \mathrm{OND} / \mathrm{HND}=3, \mathrm{~B} . \mathrm{Sc}=4, \mathrm{M} . \mathrm{Sc}$ and above $=5$ ) of the investor

$\mathrm{EXP} \quad=\quad$ Experience (dummy: no experienced $=0$, not experienced $=1$ )

$\mathrm{AI}=$ Annual personal income of the investor (naira)

HHS $=$ Household size (total number of persons feeding from the investor's pot/house)

$\mathrm{HEH}=$ Household entrepreneurial history (father/mother $=1$, brother $/$ sister $=2$, uncle $=3$, grandparents $=4$ ) 


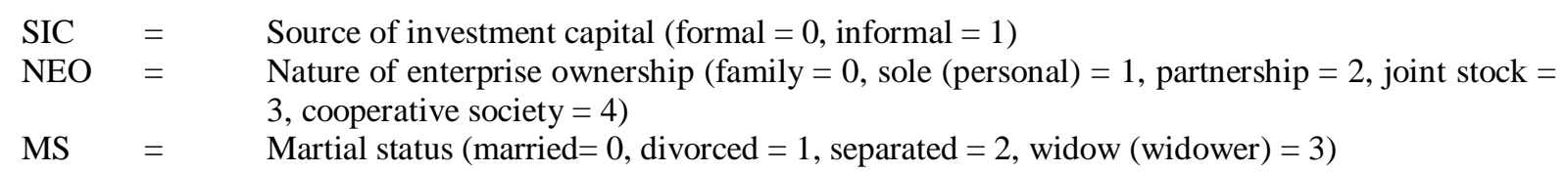

\section{Factor Analysis}

Based on the factors considered, the Principal Component Analysis (PCA) or Factor Loading was adopted for the study and by the application of Kaiser's rule of thumb (Kaiser developed a rule of thumb of 0.4 as a minimum loading weight which a factor can have before it can be isolated as being positive to the attribute in question), the factor model was expressed mathematically as:

$$
\begin{aligned}
& \mathrm{Y}_{\mathrm{i}}=\beta_{\mathrm{io}}+\beta_{\mathrm{i} 1} \mathrm{~F}_{1}+\beta_{\mathrm{i} 2} \mathrm{~F}_{2}+\beta_{\mathrm{i} 3} \mathrm{~F}_{3}+\ldots \ldots+\beta_{\mathrm{in}} \mathrm{F}_{\mathrm{n}}+\mathrm{e}_{\mathrm{i}} \\
& \text { Where, } \\
& \mathrm{B}_{\mathrm{i}}=\text { parameters or loadings. Hence, } \mathrm{B}_{1}-\mathrm{B}_{\mathrm{n}} \text { is the loading of variable } \mathrm{Y}_{\mathrm{i}} \text { on factors, } \mathrm{F}_{\mathrm{n}} .
\end{aligned}
$$

\section{Results and Discussion}

The age of an investor has been identified to have influence on the type of agribusiness invested by entrepreneurs in Southeast Nigeria. From Table 1, agro-investors whose age are within the age bracket of $40-$ 59 years were found to be more active in farm input supply (60\%), farm processing (55\%), and marketing/distribution (54\%). Thus, a strong indication that entrepreneurial activities in South-East, Nigeria were dominated by the active investors. However, the study shows that older investors (investors whose age is greater than 60 years) are more in farm production. This finding thus, corroborates Graham (1999) who opined that younger agro-entrepreneurs invest in less stressful agro-enterprises such as processing, supply and distribution, whereas the older investors tend to invest their resources production of arable crops due to environmental concerns or regulations and again they are able to have a very high efficiency in their production and are more confident that they can handle difficulties/problems that can occur in the farm business hence, are not worried about the risks.

The study reveals that men (males) are more active in certain agribusiness activities. This was attested by $97 \%$ of male agro-entrepreneurs that are into farm input supply and farm production. However, female gender has been identified to be more active in agro-processing $(55 \%)$ than the males. This collaborates the finding of Ajayi (1995) that processing enterprises are predominantly by females in Nigeria and indeed, most African societies. In similar way, the multivariate analysis result of Ellis, Manuel, and Blackden (2006) confirms that in several countries like Democratic Republic of Congo, Madagascar, Mauritius, Morocco, Namibia, Niger, South Africa, and Uganda, enterprises in the textiles and other manufacturing sector are largely owned by women than men. But in other countries (Angola, Cape Verde, Gambia, Madagascar, Mali, Mauritania, Senegal, Tanzania, and Uganda), processing enterprises are less likely to be owned by women than enterprises in other sectors. The study identified marketing and distribution of agricultural products as the only agribusiness sector that both males and females share equal role. The high dominance of males in the agribusiness ventures can be attributed to the fact that males have greater access to investment capital than the females who have greater role in household domestic activities.

The cross-tabulation of educational status on the agro-enterprises engaged by the agro-entrepreneurs has shown that educational attainment of an individual has a way of shaping the type of agribusiness enterprise one ventures into. On this note, the study identified holders of secondary school certificate as the major players in farm input supply, farm processing and distribution. Whereas, primary school certificate holders (43\%) have been identified to be the major players in farm production. These findings were justified as farm input supply; farm processing and distribution demand higher academic proficiency than farm production that can be performed by every individual whether educated or not as it involves production of arable crops and rearing of livestock.

The income level of an individual plays a great role in shaping the type of agribusiness enterprise to venture into. From the cross-tabulation result, it was observed that investors whose annual income ranges between $\$ 501,000.00-\$ 1,000,000.00$ are mainly into farm input supply. This finding is justified on the ground that the supply of farm inputs such as fertilizer and other agrochemicals is capital intensive and as such the investors in the area should have enough start-up capital. However, entrepreneurs with annual income of between $\$ 101,000$ - $\$ 500,000$ invested more farm production, processing, distribution and marketing of agricultural products. Thus, the finding justifies Ezike (2011) who reported that average annual income of N185,987.00 of the Ebonyi State Fadama III investors. The number of years an entrepreneur spends in a particular agribusiness enterprise determines how experience such investor is in that particular sub sector. The analysis in this area shows that investors with less than 5 years and grater than 20 years experience are more in farm input supply. This finding is justified as investors with less than five years experience are those involved in the supply agro-chemicals such as herbicides which is a new innovation for farmers in Southeast that practice 
zero tillage. Again, investors with grater than 20 years experience are those involved in the supply of seedlings and fertilizers that has been inputs for farm production. However, entrepreneurs that have stayed between $6-10$ years, $11-15$ years, and $16-20$ years were those entrepreneurs that were into farm processing, distribution/marketing, and farm production respectively.

Married entrepreneurs have been identified to be principal investors in the key areas of agribusiness as attested by $65 \%, 74 \%, 76 \%$, and $69 \%$ of them that engaged in farm input supply, farm production, farm processing, and marketing/distribution respectively.

The preponderance of investors whose father/mother are agro-entrepreneurs has been identified to have had influence in the choice of their investment hence, such investors invest more in farm input supply (40\%) and processing (42\%) than any other subsector as, entrepreneurs without entrepreneurial history are more in marketing/distribution (41\%) of agricultural products.

Table 1: Cross-tabulation of Socioeconomic Variables of the Investors on the Agribusiness Investments in

\begin{tabular}{|c|c|c|c|c|c|c|c|c|}
\hline & & & South & , Nigeria & & & & \\
\hline $\begin{array}{l}\text { Socioeconomic } \\
\text { variables }\end{array}$ & Mean & Description & $\begin{array}{l}\text { Farm } \\
\text { Input } \\
\text { supply }\end{array}$ & $\begin{array}{l}\text { Farm } \\
\text { productio } \\
\text { n }\end{array}$ & $\begin{array}{l}\text { Farm } \\
\text { process } \\
\text { ing }\end{array}$ & $\begin{array}{l}\text { Market } \\
\text { ing/dist } \\
\text { ributio } \\
\text { n }\end{array}$ & $\begin{array}{l}\text { Pearson } \\
\text { Chi- } \\
\text { square }\end{array}$ & $\begin{array}{l}\text { Likelihoo } \\
\text { d ratio }\end{array}$ \\
\hline Age (years) & 43 & $\begin{array}{l}20-39 \\
40-59 \\
>60\end{array}$ & $\begin{array}{l}35(29.2) \\
72(60.0) \\
13(10.8)\end{array}$ & $\begin{array}{l}43(35.8) \\
6(5.0) \\
71(59.2)\end{array}$ & $\begin{array}{l}31(39.7 \\
) \\
43(55.1 \\
) \\
4(5.1)\end{array}$ & $\begin{array}{l}17(40.8 \\
) \\
23(54.8 \\
) \\
2(4.8)\end{array}$ & 1337.675 & 813.062 \\
\hline Gender & & $\begin{array}{l}\text { Male } \\
\text { Female }\end{array}$ & $\begin{array}{l}116(96.7) \\
4(3.3)\end{array}$ & $\begin{array}{l}116(96.7) \\
4(3.3)\end{array}$ & $\begin{array}{l}27(34.6 \\
) \\
51(55.4\end{array}$ & $\begin{array}{l}21(50.0 \\
) \\
21(50.0\end{array}$ & 44.671 & 48.676 \\
\hline $\begin{array}{l}\text { Annual Income } \\
\text { (\#) }\end{array}$ & 573.779 & $\begin{array}{l}<100,000 \\
101,000-500,00 \\
501,000-1,000,000 \\
1,100,000-1,500,000 \\
>1,500,000\end{array}$ & $\begin{array}{l}8(6.6) \\
40(33.3) \\
65(54.2) \\
3(2.5) \\
4(3.3)\end{array}$ & $\begin{array}{l}5(4.2) \\
90(75.0) \\
20(16.7) \\
3(2.5) \\
2(1.7)\end{array}$ & $\begin{array}{l}3(3.8) \\
55(70.5 \\
) \\
11(14.1 \\
) \\
2(2.6) \\
5(4.2)\end{array}$ & $\begin{array}{l}1(2.4) \\
26(61.9 \\
) \\
10(23.8 \\
) \\
2(4.7) \\
3(7.1)\end{array}$ & 2524.932 & 1042.593 \\
\hline Marital status & & $\begin{array}{l}\text { Single } \\
\text { Married } \\
\text { Divorced } \\
\text { Widowed }\end{array}$ & $\begin{array}{l}15(12.5) \\
105(65.0) \\
0(0.0) \\
0(0.0)\end{array}$ & $\begin{array}{l}24(20.0) \\
89(74.2) \\
3(2.5) \\
4(3.3)\end{array}$ & $\begin{array}{l}17(21.8 \\
) \\
60(76.9 \\
) \\
0(0) \\
1(1.3)\end{array}$ & $\begin{array}{l}9(21.4) \\
29(69.1 \\
) \\
0(0) \\
4(9.5)\end{array}$ & 131.569 & 78.816 \\
\hline $\begin{array}{l}\text { Household } \\
\text { Entrep. History }\end{array}$ & & $\begin{array}{l}\text { No history } \\
\text { Father/mother } \\
\text { Brother/sister } \\
\text { Uncle/aunty }\end{array}$ & $\begin{array}{l}34(28.3) \\
48(40.0) \\
26(21.7) \\
12(10.0)\end{array}$ & $\begin{array}{l}77(64.2) \\
40(33.3) \\
2(1.7) \\
1(0.8)\end{array}$ & $\begin{array}{l}29(37.2 \\
) \\
33(42.3 \\
) \\
12(13.4 \\
) \\
4(5.1)\end{array}$ & $\begin{array}{l}17(40.5 \\
) \\
11(26.2 \\
) \\
0(0) \\
14(33.3 \\
)\end{array}$ & 350.027 & 318.154 \\
\hline
\end{tabular}

Source: Field survey, 2011 


\section{Determinants of Investment Decision}

Apart from some personal attributes that influence investment decisions, Table 2 shows that that favourable government policy on agribusiness investment was one of the vital factors that influenced investment in agribusiness sector in Nigeria. This was justified on the ground that Nigeria have taken a proactive role in attracting private sector agribusiness investments by offering various incentives geared to the sector, such as tax holidays within the first few years of an agribusiness establishment, deferred royalty payment and zero duty on agricultural machinery (van-Hear, 2008). Some of other programmes aimed at influencing investors to invest in agribusiness are incorporated at regional level initiatives such as the African Union's New Partnership for Africa's Development (NEPAD), the Comprehensive Africa Agriculture Development Programme (CAADP) and the Alliance for a Green Revolution in Africa (AGRA) (Van Stel, 2005). Other special programmes initiated by the government of Nigeria to boost entrepreneurial activities include; National Directorate of Employment scheme (NDE), establishment of the Bank of Industry, promotion of the Small and Medium Enterprises Development Agency of Nigeria, (SMEDAN), and the Small and Medium Industries Equity Investment Scheme (SMIEIN).

The degree of risk associated with agribusiness investments was identified as a strong indicator for agribusiness and the decision to invest in agribusiness is accompanied by a thorough understanding of the risks involved. It is an accepted norm that the higher the business risk the higher the financial returns if the investor can endure it. The level of risk associated with a business has the capacity to sway-off many investors as many entrepreneurs attempt to avert risk by venturing into a less risky business. Agriculture across the board is notorious for the volatility of its returns. Environmental factors such as drought, disease and natural disasters as well as volatility in commodity prices and costs, including oil prices affecting the cost of transportation can severely reduce the return on investment. The finding is justified by that of Miguel, et al. (2004) who inferred that private sector investors face significant economic risks due to the instability of political and financial institutions, uncertainty about government policy, incomplete or non-existent markets, war, corruption, and social issues in the region, among other factors.

The result further revealed that people with cognitive experience in self employment are more likely to invest than those who have no previous knowledge in self employment. This concurs with that of Ajzen (1991) who reported that having relevant entrepreneurial and managerial experience confers upon an investor a greater sense of perceived behavioural control. The investor will have a stronger belief in his own ability to target good investments and contribute to the growth of the sector. However, Weissleder and Heckelei (2008) inferred that lack of knowledge or experience is responsible for inability to recognize opportunities, for failure to plan with sufficient accuracy, or for fear of not being able to execute plans properly.

Market size has been identified as a strong determinant of investment in agribusiness sector. This is due to the fact that the size of market explains how massive the product of an agribusiness firms could be consumed. It equally implied better prospects for an investor since it equates to a greater demand for its goods and services, and offers the investor economies of scale. This was in consonance with the finding of Weissleder and Heckelei (2008) who observed a similar positive relationship between agribusiness investment and market size in Mediterranean countries. This result does not corroborate Dauda (2007), who noted that small market size is not a constraint to growth in an agribusiness investment.

Table 2: Varimax rotated component matrix on the factors influencing investment decisions among agribusiness investors in South-East, Nigeria

\begin{tabular}{llccc}
\hline S/N & Factors & \multicolumn{3}{c}{ Components } \\
\cline { 3 - 5 } & & $\begin{array}{c}\text { Economic } \\
\text { factors }\end{array}$ & $\begin{array}{c}\text { Social } \\
\text { factors }\end{array}$ & $\begin{array}{c}\text { Environmen } \\
\text { tal factors }\end{array}$ \\
\hline $\mathrm{V}_{1}$ & Start-off capital & 0.664 & -0.033 & -0.124 \\
$\mathrm{~V}_{2}$ & Location of the business environment & -0.011 & -0.151 & 0.702 \\
$\mathrm{~V}_{3}$ & Government policy on entrepreneurship & 0.750 & 0.090 & 0.364 \\
$\mathrm{~V}_{4}$ & Inherent risk in business was low & 0.610 & 0.098 & 0.109 \\
$\mathrm{~V}_{5}$ & Experience in self employment & 0.881 & 0.137 & 0.082 \\
$\mathrm{~V}_{6}$ & Available social and public infrastructure & -0.026 & 0.036 & 0.217 \\
$\mathrm{~V}_{7}$ & Inflation rate & 0.805 & 0.174 & -0.147 \\
$\mathrm{~V}_{8}$ & Market size & 0.471 & 0.301 & 0.006 \\
\hline
\end{tabular}

Source: Field Survey, 2011

Probit analysis of the effect of socio-economic characteristics on the determinants of investment decision

The socio-economic attributes of agribusiness investors in South-East Nigerian have been found to have significant effect on investment decision. This was explained by the $\left(\chi^{2}\right)$ of 9368.836 and the Pseudo $\mathrm{R}^{2}$ of 
0.465 that was significant at $5 \%\left(\mathrm{R}^{2}>\right.$ significant level; 0.05$)$ and hence provides sufficient explanation about the model used. Specifically, the results of the individual socioeconomic attributes show that:

Age has a positive effect on the decision of an individual to invest in agribusiness sector. This was justified by the fact that age bore a positive coefficient and was statistically significant at $1 \%(\mathrm{P}<0.01)$ level. This is in line with the a priori expectation as the age of an investor was expected to have an effect on the investment behaviour because as the age of individual increases so do his quest to go into investment increases as such investment will later serve as a financial shield on retirement. This finding is in contrast to that of Berem et al. (2010), who found that age to be inversely related to the probability of one investing in honey agribusiness because as one advances in age they become risk averse and thus tend to avoid new ventures, on whose performance they are not certain.

The coefficient of educational status was positive and significant at $1 \%(\mathrm{P}<0.01)$. This implies that educated individual has better potential to choose the area to invest as he knows the nitty-gritty of investment. Formal education provides entrepreneurs with a greater capacity to learn about new production processes and product designs, offer specific technical knowledge conducive to firm expansion, and increase owners' flexibility. In justification of the finding, De Bondt (1998) reported that well educated people understands better the risks and uncertainties that are found in business and are scientifically equipped to understand the complexities of these eventualities. Hence, it could be inferred that educated investors could see various issues and problems under different angle as compared to uneducated investors. This finding refutes that of Berem $e t$ al. (2010) who inferred that the level of education of household head had an inverse relationship to the probability of investing in agribusiness value addition.

Previous entrepreneurial experience was hypothesized to improve an individual's perception of his own ability to select good investment targets and to control these for optimal outcome. On this note, the study identified previous experience in similar business(s) to have had a positive effect on the decision of an individual to invest in agribusiness sub sector as attested from the positive coefficient of the variable though not statistically significant. This finding implies that experience has a direct relationship with investment decision as increase in one's experience in the line of business will bring about increase in his/her quest to invest his resources. This finding is in inconsonance with Ngore, Mshenga, Owuor and Mutai (2011), who found experience in meat agribusiness to have directly influenced investment in meat production and value added to meat products in Egerton, Kenya. In a similar way, Armagan and Ozden (2010) found experience to be positively related to investment in dairy agribusiness in Turkey. Penrose (1995) posited that prior work experience augments task based efficiency, and prompts an individual to seek for similar type of investments. Again, prior experience with a particular task reduces the need for cognitive attention to do similar tasks in future.

The study reveals that the annual income has significant effect in investment decision of agribusiness entrepreneurs. This was shown by the positive coefficient of annual income and its statistical significance at $1 \%$ $(\mathrm{P}<0.01)$. This implied that increase in investor's annual income will increase his/her quest to invest. Again, increase in income allows the individual to spread her assets more widely across investment categories, and therefore, also include riskier investment vehicles such as informal investments in her portfolio..

Household entrepreneurial history has significant effect on individual's decision to invest in agribusiness. This is evident from the positive coefficient of household entrepreneurial history and its significance at $1 \%(\mathrm{P}<0.01)$. This finding is in line with a priori expectation as individuals from the family of entrepreneurs will have a greater desire to join the line of family members that are entrepreneurs and hence the desire to invest resources in business.

The coefficient of source of investment capital was positive and statistically significant at $5 \%$ level. This implies that an investor that has a well defined source of capital before hand will have greater quest to invest in agribusiness.

The decision on who owns an enterprise is a vital variable in determining investment decision. From the result, it was observed that nature of investment ownership has an inverse effect on the determinant of investment decision of agribusiness investors. That is to say that whoever owns an investment has no effect on the investment decision of agribusiness investors. The finding negates the a priori expectation. Meanwhile, Wetzel (1983) reported that only a very small proportion of investors $(2 \%)$ can invest in ventures owned by entrepreneurs with which they are not personally acquainted. Furthermore, he deduced that investment can be "family investment" or "business angels". 
Table 3: Coefficient Estimates of Probit Regression Model of the Effect of Socioeconomic Attributes of Investors on Agribusiness Investment Decisions

\begin{tabular}{lllll}
\hline Variables & Parameter & Coefficients & $\begin{array}{l}\text { Standard } \\
\text { Error }\end{array}$ & Z-value \\
\hline Constant & & -1.170 & 0.061 & $-19.286^{*}$ \\
Age & $\beta_{0}$ & 0.004 & 0.01 & $4.319^{*}$ \\
Gender & $\beta_{1}$ & -0.061 & 0.014 & $-4.213^{*}$ \\
Educational Status & $\beta_{2}$ & 0.049 & 0.002 & $25.692^{*}$ \\
Experience & $\beta_{3}$ & 0.003 & 0.013 & 0.264 \\
Annual Income & $\beta_{4}$ & 0.000 & 0.000 & $-22.026^{*}$ \\
Household Size & $\beta_{5}$ & -0.017 & 0.01 & $-13.069^{*}$ \\
Household Entrep. History & $\beta_{6}$ & 0.021 & 0.004 & $5.158^{*}$ \\
Source of Invest. Capital & $\beta_{7}$ & 0.080 & 0.019 & $4.299^{* *}$ \\
Nature of Ownership & $\beta_{8}$ & -0.052 & 0.009 & $-5.979^{*}$ \\
Marital Status & $\beta_{9}$ & -0.007 & 0.011 & -0.691 \\
Pearson Goodness-of-Fit = 9368.836* & $\beta_{10}$ & & & \\
\hline
\end{tabular}

$* \mathrm{P}=0.01(99 \%) ; * * \mathrm{P}=0.05(95 \%) ;$ Chi-square $(\chi 2)=9368.836$, Pseudo $\mathrm{R}^{2}=0.465$

Source: Field Survey, 2011

Inter-correlation analysis of selected socio-economic characteristics of agribusiness investors in Southeast, Nigeria with investment decisions

From the inter-correlation analysis (Table 4), the interrelationship that exists between the socioeconomic characteristics of the agro-entrepreneurs in relation to investment determinants marital status and gender $\left(0.688^{*}\right)$ was substantially inter-correlated thus, an indication that combined ideas of male and female will result in proper improper decision to invest resources in agribusiness venture(s). Hence, a justification of the saying that two good head are better than one. Again, there was a substantial $(0.622 *)$ inter-relationship between entrepreneur's annual income and level of education. This implies that a combined increase in the annual income and the educational level of an individual will foster a good decision to invest in agribusiness as a wealthy individual that is not educationally balanced will find it difficult to take a good decision on investment especially agricultural business that is characterised by risks and uncertainties. Similarly, the inter-relationship between experience and level of education was found to be highly correlated $0.739 * *(74 \%)$. This then implies that an investor that is well educated and has cognitive experience in entrepreneurship will have better vision to invest wisely in agribusiness ventures and vice versa. The inter-relationship between household entrepreneurial history and individual experience which was $0.515^{*}(52 \%)$ is indicates that entrepreneurs with household entrepreneurial history coupled with individual experience in entrepreneurship will have better decision to invest in agribusiness.

Table 4: Inter-correlation analysis of selected socio-economic characteristics of agribusiness investors in South-east, Nigeria with investment decisions

\begin{tabular}{|c|c|c|c|c|c|c|c|c|c|c|c|}
\hline \multirow{10}{*}{ 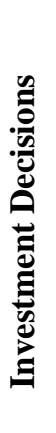 } & & AG & GEN & HHS & LED & AI & EXP & SIC & NEO & MS & НEH \\
\hline & $\begin{array}{l}\text { AG } \\
\text { GEN }\end{array}$ & $\begin{array}{l}1.000 \\
-.059\end{array}$ & & & & & & & & & \\
\hline & HHS & $.432^{* *}$ & .083 & 1.000 & & & & & & & \\
\hline & LED & $.163^{* *}$ & .013 & $-.171^{* * *}$ & 1.000 & & & & & & \\
\hline & AI & $.256^{* *}$ & $-.161^{* *}$ & $.389^{* * *}$ & $.622^{*}$ & 1.000 & & & & & \\
\hline & EXP & .075 & .013 & .044 & $.739 * *$ & .093 & 1.000 & & & & \\
\hline & SIC & $-.187^{* *}$ & -.040 & -.068 & $-.134^{*}$ & $.701^{* * *}$ & -.091 & 1.000 & & & \\
\hline & NEO & .020 & -.061 & .055 & .011 & .037 & $-.123^{*}$ & .011 & 1.000 & & \\
\hline & MS & $.421^{* *}$ & $.688^{*}$ & $.130^{*}$ & $-.178^{* *}$ & $.136^{* * *}$ & .042 & -.056 & -.045 & 1.000 & \\
\hline & HE & -.090 & $.155^{* * *}$ & -.008 & $.183^{* *}$ & .030 & $.515^{*}$ & -.060 & -.038 & -.056 & 1.000 \\
\hline
\end{tabular}

** Significant at 0.01 level, * significant at 0.05 level, Source: Field Survey, 2011

$\begin{array}{lll}\mathrm{MS} * \mathrm{GEN} & = & .688^{*} \\ \mathrm{AI} * \mathrm{LED} & = & .622 * \\ \mathrm{EXP} * \mathrm{LED} & = & .739 * \\ \mathrm{HEH} * \mathrm{EXP} & = & .515 *\end{array}$


Legends

$\mathrm{AG}=\mathrm{Age}, \mathrm{GEN}=$ Gender, HHS = Household size, $\mathrm{LED}$ = Level of education, AI = Annual income,

EXP $=$ Experience, SIC $=$ Source of investment capital, NEO = Nature of enterprise ownership,

MS = Marital Status, $\mathrm{HEH}=$ Household entrepreneurial history

\section{Conclusion and recommendations}

The combined effects of age, educational status, experience, source of investment capital, annual income, and household entrepreneurial history, inadequate start-up capital, business location, favourable government policy on entrepreneurship, experience in self employment, high rate of inflation, market size have been identified as the major determinants of investment decision among agribusiness investors in Southeast Nigeria.

Based on the findings, the study recommended the provision of conducive investment climate for agribusiness investors. This entails the provision of those things that will attract both local and foreign direct investments into agribusiness sector. These include tax holidays, investment infrastructures, reduction in social vices such as kidnapping and activities of boko haram.

\section{References}

[1]. African Agribusiness and Agro-industries Development Initiative (3ADI), 2010. Development of agribusiness and agroindustries in Africa. A paper delivered on the conference organised by 3ADI in Abuja, Nigeria: 8 - 10 March, 2010.

[2]. Ajzen, I. 1991. The Theory of Planned Behaviour. Organisational Behaviour and Human Decision Processes. $\quad$ 50(2): 179-211.

[3]. Anon. 2010. Investing in Agribusiness. http://www.forexrobotreview.net (23/08/10).

[4]. Armagan, G. and Ozden, A. 2010. Entrepreneurial Attitudes and Behaviours in Small-scale Dairy Farms in $\quad$ Turkey. 111 EAAE-IAAE Seminar 'Small Farms: Decline or Persistence. University of Kent, $\quad$ Canterbury, UK 26th-27th June 2009.

[5]. Berem, R.M., Obare, G.A. and Owuor, G. 2010. Is Value Addition in Honey a Panacea for Poverty Reduction in the ASAL in Africa? Empirical Evidence $\quad$ from Baringo District, Kenya. Contributed paper presented at the joint 3rd African Association of Agricultural Economists (AAAE) and 48th Agricultural Economists Association of South Africa (AEASA) conference, Cape Town, South Africa, September19-23.

[6]. Dauda, O. 2007. Entrepreneurship Education. Learning Organisation. 5(3): 144. $155 . \quad$ http://www.isebe2007.org/view.php. $15 / 03 / 2011$

[7]. De Bondt, W. F. M. 1998. Behavioural economics: A portrait of the individual investor. European Economic Review. 42 831- 844.

[8]. Ellis, A., C. Manuel, and C. M. Blackden. 2006. Gender and Economic Growth in Uganda: Unleashing the Women. Washington, DC: World Bank, Directions in Development.

[9]. Ezike, K. N. N. 2011. Impact Assessment of Household Income Generation, Progression and Sustainability State FADAMA III Implementation. A mid-term review of Ebonyi State FADAMA.

[10]. Graham, J. R. 1999. Herding among Investment Newsletters: Theory and Evidence. Journal of finance. 54

Power of

[11]. Hawkins, S. A. and Hastie, R. 1990. Hindsight: Biased judgements of past events after the outcomes are known. Psychological Bulletin. 107: 311-327.

[12]. Hirshleifer, J. 1995. Investment decision criteria. Prentice Hall, Englewood, Ciffs, N. J. Pp. 97-102.

[13]. Marco, M. and Paolo, L. 2010. Investment Decision-Making and Hindsight Bias. Journal of Finance. New York. 53(5): 1775-1798.

[14]. Miguel, E., Satyanath, S., and Sergenti, E. 2004. Economic Shocks and Civil Conflicts: An Instrumental Approach. Journal of Political Economy, 112 (4).

[15]. National Population Commission (NPC) 2006. Official Population Figure of Southeast Nigeria. A report of NPC Abuja, Nigeria.

[16]. Ngore, P.M. Mshenga, P. M, Owuor, G. and Mutai, B. K. 2011. Socioeconomic Factors Influencing Meat by Rural Agribusinesses in Kenya. Current Research Journal of Social Sciences. 3(6): 453 - 464.

Value Addition

[17]. Penrose, E T. 1980. The Theory of the Growth of the Firm. Basil Blackwell, Oxford, UK. P.67.

[18]. van-Hear, N. 2008. Attracting Agribusiness in Nigeria. The Multinational Monitor. 6(12): 1 - 6.

[19]. van Stel, A., 2005, Compendia: Harmonizing business ownership data across countries and overtime. International Entrepreneurship and Management Journal. 1(1): 105-123.

[20]. Weissuleder, L. M. and Heckelei, T. 2008. Analysing Major Determinants of European FDI into the Mediterranean Countries. Paper presented in the 12th Congress of the European Association of Agricultural Economist, Bon, Germany.

[21]. Wetzel , W.E. 1983. Angels and Informal Risk Capital. Sloan Management Review. 24: 23 - 34 